\title{
EDITORIAL Italy, Covid 19, 2020
}

When, in January 2020, we wrote our first editorial for Modern Italy's $25^{\text {th }}$ anniversary, we looked forward to an exciting and rewarding final year as the journal's general editors - hoping that it would end with a stimulating ASMI conference and a good handover party. At that stage no-one except perhaps the most pessimistic epidemiologist might have foreseen that a microorganism then known by the generic term 'Corona virus' would soon reach the western headlines through its seizure of, and spread through, northern Italy. By late February though, it was clear that Italy was for some reason particularly hard-hit by the virus. On 9 March Italy enacted unprecedented national quarantine measures, drawing world attention to its unenviable status as the disease's European epicentre. Italy then held the world's pained attention for the rest of the month until other nations well and truly caught up. For Italians and scholars of Italian studies, the nation's position on the Covid league was a confoundingly unenviable primacy.

Though the situation has yielded a huge amount to ponder, we are neither qualified and nor do we have the space to explore those issues here ourselves. In future the phenomenon will no doubt offer a rich field of analysis for scholars, but for now, we would simply like to take this opportunity to convey the warmest possible saluti and, where appropriate, condoglianze, to Italians worldwide, in recognition of what Italy has recently been through.

Despite the challenges imposed on everyone by the worldwide health situation, we are pleased to be able to bring you a full and varied issue of Modern Italy, thanks to the hard work of authors, referees, book review editors, and the production team at CUP. However, Covid 19 has prompted one small change to the planned line-up of this issue: in place of our intended editorial on the journal's early days and subsequent history, we commissioned Milan-based historian Arianna Arisi Rota to write a personal essay about what it felt like to be a scholar living and working in Italy's worst-hit area, Lombardy, during the Covid crisis. The resulting article, written at fairly short notice, opens this issue under the 'Contexts and Debates' rubric. Our own piece will effectively become our farewell editorial in 2020's final issue.

The current issue presents five diverse research articles. Christopher Lee and Claire Kennedy's study of Francesco De Pinedo's 1925 flight from Italy to Australia provides a fascinatingly transnational interpretive foil to the more propagandized transatlantic flights of the 1930s. Next, sociologists Alberto Baldissera and Federica Cornali offer a nuanced study of human capital, education, and literacy, across Italy's macro-regions - looking not only at the closing gap between north and south, but a widening of the differences between north-east and north-west. Bruno Bracalente, Davide Pellegrino and Antonio Forcina provide a longitudinal analysis of Italy's disappearing 'red regions', examining the period from 1953 to 2019. They use Umbria as a case study, paying particular attention to the electoral relationship between left-wing and populist parties. Aptly titled for the times (but in fact submitted before the onset of Covid 19), Annachiara Mariani's 'Viral (per) versions of power' provides a psychological reading of Paolo Sorrentino's Berlusconi in the film diptych Loro 1 and Loro 2. Finally, Lucia Pozzi's article on the regulation of morality and eugenics 
under fascism offers a searching analysis of the 'productive alliance' between Italian Fascism and the Catholic Church.

The Reviews section offers a unusual treat: a review essay on 'New approaches to Neorealism in Italian cinema' by Damiano Garofalo. As editors, we always hoped to increase the publication of similar essays, as they are of great interest and utility to readers. Unfortunately, the newly hegemonic regimes of research assessment are blind to the skill, knowledge, and labour required to write such essays, and there are dwindling incentives to write them. For this reason we are particularly grateful to Dott. Garofalo for accepting our commission of this article.

We wish you good reading - and good health.

Penelope Morris and Mark Seymour 